Szegedi Tudományegyetem Általános Orvostudományi Kar, I. Belgyógyászati Klinika, Nephrologia-Hypertonia Centrum, Szeged

\title{
Gondolatok a direkt orális véralvadásgátló szerek használatáról krónikus vesebetegségben*
}

\author{
Ábrahám György dr.
}

* A szerkesztőbizottság felkérésére készített kézirat

\section{Öszefoglalás}

A krónikus vesebetegség, a beszükült vesefunkció szignifikánsan növeli a cardiovascularis morbiditás és mortalitás kockázatát. A legnagyobb veszélyt a thromboemboliás szövődmények jelentik, különösen a gyakori társbetegségként jelentkezö pitvarfibrilláció esetén. Az antikoaguláns terápia szignifikánsan csökkenti a stroke, a koszorúer-thrombosis és a szisztémás embolizáció gyakoriságát. A szerzö a direkt antikoagulánsokkal szerzett klinikai tapasztalatokat tekinti át warfarinnal történt összehasonlításban, különös tekintettel a csökkent vesefunkcióra. Ugyanakkor a beszükült vesemüködés, annak mértékével arányosan, növeli a vérzés kockázatát és csökkenti az antikoagulálás protektiv hatását. Jelenleg nem állnak rendelkezésre a direkt antikoaguláns szerek egymással szembeni összehasonlító vizsgálatai, így a terápiát az adott betegre vonatkoztatva individuálisan kell megválasztani és a gondozást megtervezni.

Kulcsszavak: direkt antikoaguláns, apixaban, dabigatran, edoxaban, rivaroxaban, krónikus vesebetegség, végstádiumú vesebetegség

\section{Thoughts about the treatment with direct oral anticoagulants in chronic kidney diseases}

Summary: Chronic kidney disease, renal dysfunction significantly increases the risk of cardiovascular morbidity and mortality. The biggest threat are the thromboembolic complications, especially in the frequent co-occurring disease atrial fibrillation. Anticoagulant therapy significantly reduces the risk of the stroke, coronary thrombosis and systemic embolism prevalence. The author considers the clinical experiences with the treatment of direct anticoagulants for comparison with warfarin, particularly with regard to reduced kidney function. However, renal impairment, in proportion of its degree increases the risk of bleeding and reduces the protective effect of anticoagulation. Currently, there are no direct comparative studies of direct anticoagulation agents against each other, so treatment should be selected and tailored based on the care given to the patient individually.

Keywords: direct anticoagulant, apixaban, dabigatran, edoxaban, rivaroxaban, chronic kidney disease, end stage renal disease

Rövidítések

AUC: görbe alatti terület: (area under curve); Cl: megbízhatósági tartomány (confidence interval); CV: cardiovascularis; DOAC: direkt orális antikoaguláns; EHRA: Európai Szívritmus Társaság (European Heart Rhythm Association); ESRD: végstádiumú veseelégtelenség (end stage renal disease); HR: kockázati ráta (hazard ratio); INR: a prothrombin aktivitás mérőszáma (international normalized ratio); KVB: krónikus vesebetegség; PF: pitvarfibrillá- 
ció; RE-LY: Randomized Evaluation of Long-Term Anticoagulation Therapy (klinikai tanulmány); TAG: thrombocytaaggregáció-gátlás; TE: thromboembolia; VKA: K-vitamin-antagonista; VTE: vénás thromboembolia; vWF: von Willebrand-faktor

A krónikus vesebetegség, a beszűkült vesefunkció szignifikánsan növeli a cardiovascularis (CV) morbiditás és mortalitás kockázatát. Keith és munkatársai 5 éven át követtek 27998 olyan beteget, akiknek kiinduláskor vesefunkciója az eGFR $<90 \mathrm{ml} / \mathrm{min} / 1,73 \mathrm{~m}^{2}$ tartományban volt. Mindaddig gyüjtötték az adatokat, amíg vesepótló kezelés nem vált szükségessé, illetve nem következett be elhalálozás. A veseelégtelenek között, annak mértékével arányosan, gyakoribb volt a pangásos szívelégtelenség, a koszorúér-betegség, a vérszegénység, a végstádiumú veseelégtelenség (ESRD) kialakulása, a CV halálozás előfordulása, míg a hypertensio prevalenciáját a veseelégtelenség stádiuma érdemben nem befolyásolta. A veseelégtelenség 2-es, 3-as, 4-es stádiumaiból kiindulva az 5 éves futamidő alatt 2-3-19\%-ban alakult ki ESRD, míg a CV halálozás gyakorisága 20-25-43\% volt. Így azt a megalapozott következtetést lehetett levonni, hogy krónikus vesebetegek esetében nagyobb a CV halálozás valószínűsége, mint a végstádiumú vesebetegség (ESRD) kialakulásáé. ${ }^{1}$

Az is tény, hogy a dializált vesebetegek körében az életkortól függetlenül mintegy 10-20-szor nagyobb a CV mortalitás gyakorisága, mint az átlagnépességben. Ez a megfigyelés, amely az arrhythmiákra, cardiomyopatiákra, szívmegállásra, szívinfarktusra, ischaemiás szívbetegségre és tüdőoedemára terjedt ki, akkor is érvényben maradt, ha nem, rassz, életkor szerint hasonlították össze az adatokat a megfelelően választott átlagnépességgel. ${ }^{2}$ Olesen és munkatársai az ún. Dán regiszterben (1997-2008) vizsgálták pitvarfibrilláló (PF) krónikus vesebetegek $(n=3587)$ körében a stroke, szisztémás embolizáció, vérzés és összhalálozás bekövetkeztének kockázatát 127884 pitvarfibrilláló, de normális vesefunkciójú beteggel összehasonlítva. Azt találták, hogy a fenti sorrendben a kockázat növekedése 1,49-szeres, 2,24-szeres, illetve 2,37-szeres volt. ${ }^{3}$ A CV halálozás vezető okát a thromboemboliás (TE) szövődmények képezik. A vesefunkció közepes beszűkülése esetén ennek kockázata 2,5-szeres, míg súlyos veseelégtelenség esetén 5,5-szeresére emelkedik, ${ }^{4}$ amit ront, ha további kockázati tényezők is fennállnak (pl. tumor, thrombophilia, műtét, tartós fekvés stb.).

\section{Az antikoagulálás fontossága}

A TE szövődmények megelőzésében a hatékony antikoagulálás szó szerint élet-halál kérdése. Ugyanakkor a veseelégtelenség a haemostasis szempontjából Janus-arcú, azaz sajátos módon a prothromboticus és a vérzékeny állapot együttesen fordul elő. Prothromboticus tényezőként jelennek meg a vascularis endothelium változásai, a véralvadási faktorok emelkedett szintje (fibrinogén, VIII-as faktor, vWF stb.), az antifibrinolyticus faktorok csökkenése, a hypalbuminaemia, hyperlipidaemia, hemokoncentráció. A vérzékenységet elősegítő tényezők az urémiás toxinok, a thrombocyta-diszfunkció, az anaemia, a társbetegségek (pl. stresszfekély), a thrombocytaaggregáció-gátló (TAG) és a szteroidkezelés. ${ }^{5}$

A klinikai gyakorlat azt mutatja, hogy elsődlegesen a thrombogen hatás érvényesül. Így krónikus veseelégtelenségben sem nélkülözhető az antikoagulálás, különösen a következő kórállapotokban: nephrosis szindrómához társuló thrombosisban (főként membranosus nephropathiában), vesevéna-thrombosisban, mélyvénás thrombosisban, tüdőembólia, artériás thrombosis, PF, vénás kanülök/fistula thrombosis fennállásakor. ${ }^{6}$ Ezek közül kiemelt jelentősége van a PF-nak, amely a leggyakoribb szívritmuszavar, és különösen így van ez krónikus vesebetegség (KVB) esetén.

\section{Az antikoagulálás módja}

Nem vitatható, hogy a K-vitamin-antagonistákkal (VKA) történő antikoagulálás összességében szignifikánsan csökkentette az ischaemiás stroke, a tranzitorikus ischaemiás attak és a halálozás gyakoriságát a nem kezelt populációval összehasonlítva. ${ }^{7} \mathrm{~A}$ beszűkült veseműködés és különösen a hemodialízis azonban komoly nehézségeket támaszt e kezelési móddal szemben, mert igen nehéz az INR-értéket a kívánt 2-3 közötti tartományban tartani, hogy csak a K-vitamin-hiányt vagy az adherencia elégtelenségét említsük. További problémát 
jelent, hogy KVB-betegekben gyakori a calciphylaxis, azaz a subcutan arteriolák kalcifikációja is. ${ }^{8}$ Néhány vizsgálat azt mutatta, hogy súlyos veseelégtelenség esetén a VKA kezelés fokozta a PF-hoz társuló stroke és vérzés incidenciáját is, főként inadekvát INR-kontroll esetén. ${ }^{9}$ További komplikáció lehet VKA terápia esetén az ún. warfarinhoz kapcsolódó nephropathia is, amely a mortalitás független rizikófaktoraként is értékelhető. Jellegzetessége, hogy warfarinkezelés során akut vesefunkció-romlás alakul ki. Vesebiopsia során az alapbetegség mellett glomerularis haemorrhagia figyelhető meg; a vizeletüledékben vörösvértest-cylinderek láthatók. A megelőző INR-érték rendszerint 3 feletti. ${ }^{10}$

Új típusú, direkt orális antikoaguláns hatású (DOAC) szerek adása - Caluwé és munkatársai vizsgálatai szerint - előnyös lehet KVB-ben, mert, a warfarinnal szemben, valószínűleg nincsenek hatással a vascularis kalcifikációra. ${ }^{11}$ Figyelemre méltó, hogy DOAC alkalmazása mellett az eGFR csökkenése is kisebb mértékü a warfarinhoz képest; a különbség egy év után jelenik meg, és további 18 hónap után már $2 \mathrm{ml} / \mathrm{min} / 1,73 \mathrm{~m}^{2}$ lesz a DOAC terápia javára. ${ }^{12}$ (A szerzö a jelen közleményben a DOAC rövidítést alkalmazza. Korábban a NOAC [new oral anticoagulant - új orális antikoaguláns] rövídités is használatos volt, de e szerek már tíz éve használatban vannak, ezért „új” megjelölésük nem indokolt.)

\section{A direkt orális véralvadásgátló szerek}

A továbbiakban tekintsük át a DOAC alkalmazási lehetőségeit és az eddigi tapasztalatokat KVB-ben. A klinikai vizsgálati eredmények értékelésekor több fontos szempontot kell figyelembe venni. A DOAC szerek közül három (apixaban, edoxaban, rivaroxaban) Xa faktor gátló, míg a dabigatran direkt trombingátló szer, tehát hatásmechanizmusa eltérő. Az egyes szerek renális clearance-e más és más mértékű. A vesefunkció jellemzésére használatos eGFR kiszámítására több módszer van alkalmazásban, amelyek változó mértékben veszik figyelembe a nemi, rasszbeli, életkori stb. eltérésekből adódó különbségeket. E tényezők miatt a különböző vizsgálatok eredményeinek metaanalízis jellegü összevetése csak igen korlátozottan tehető meg, és az ebből levonható következtetéseket óvatosan kell kezelni. A 2018-as EHRA ajánlás az eGFR számítására a Cockroft-Gault-formulát javasolja, amelynek alapján a vesefunkció-beszükülés 1. táblázatban látható kategóriáit különbözteti meg. ${ }^{13}$

A továbbiakban tekintsük át az egyes hatóanyagok sajátosságait, különös tekintettel a KVB-re.

1. táblázat. A vesebetegség diagnosztikai kritériumai; a vesefunkció meghatározása és a vesefunkció-beszükülés kategóriái az EHRA 2018-as ajánlása szerint ${ }^{13}$

\begin{tabular}{|c|c|c|c|}
\hline Csökkent GFR & & & $\mathrm{GFR}<60 \mathrm{ml} / \mathrm{min} / 1,73 \mathrm{~m}^{2}$ \\
\hline $\begin{array}{c}\text { A } \\
\text { vesekárosodás } \\
\text { markerei }(\geq 1)\end{array}$ & $\begin{array}{l}\text { - excessiv albuminuria (albuminexcre } \\
\text { - a vizeletüledék eltérései } \\
\text { - tubuluskárosodás okozta elektrolit- } \\
\text { - a vese képalkotó vizsgálatokkal iga } \\
\text { - kóros szövettani lelet } \\
\text { - vesetranszplantáció utáni állapot }\end{array}$ & $\begin{array}{l}\text { iós ráta } \\
\text { lagy egy } \\
\text { lt struk }\end{array}$ & $\begin{array}{l}30 \mathrm{mg} / 24 \mathrm{~h} \text {, albumin/kreatinin hányados } \geq 30 \mathrm{mg} / \mathrm{g} \text { vagy } 3 \mathrm{mg} / \mathrm{mmol} \text { ) } \\
\text { b eltérés } \\
\text { rális károsodásai }\end{array}$ \\
\hline GFR-kategória & Krónikus vesebetegség stádiuma & GFR & Leírása \\
\hline G1 & 1 & $\geq 90$ & Normális vagy magas \\
\hline G2 & 2 & $60-89$ & Enyhén csökkent \\
\hline G3a & \multirow{2}{*}{3} & $45-59$ & Mérsékelten vagy enyhén csökkent \\
\hline G3b & & $30-44$ & Mérsékelten vagy súlyosan csökkent \\
\hline G4 & 4 & $15-29$ & Súlyosan csökkent \\
\hline G5 & 5 & $<15$ & Veseelégtelenség (vesepótló kezelés szükséges - dialízis, transzplantáció) \\
\hline
\end{tabular}

A vesefunkció becslésére DOAC szerek esetében legalkalmasabb a kreatinin clearence Cockroft-Gault-formula szerinti számítása:

( 140 - életkor[év] ) × testtömeg[kg] × ( nő: 0,85 | férfi: 1,00$) /(72 \times$ szérumkreatinin[mg/dl] )

Online kalkulátorok elérhetők: www.kidney.org/professionals/kdoqi/gfr_calculator; www.nephron.com/cgi-bin/CGSI.cgi;

www.mdcalc.com/creatinine-clearance-cockcroft-gault-equation; reference.medscape.com/calculator/creatinine-clearance-cockcroft-gault 


\section{Dabigatran}

A dabigatran volt az első DOAC szer, amelynek klinikai alkalmazását - a RE-LY vizsgálat eredményei alapján - az FDA 2010 októberében engedélyezte. Hatásmechanizmusát tekintve direkt trombingátló, amelynek vesekiválasztása $80 \%$, ezért beszűkült vesefunkció esetén könnyen akkumulálódhat.

Átlagosan 12-17 órás a féléletideje. Ha az eGFR 30-50 $\mathrm{ml} / \mathrm{min} / 1,73 \mathrm{~m}^{2}$, akkor $13-23$ órára is növekedhet, míg <30 $\mathrm{ml} / \mathrm{min} / 1,73 \mathrm{~m}^{2}$ esetén elérheti a $23-25$ órát is. ${ }^{14} \mathrm{~A}$ RE-LY vizsgálatban a PF-betegek 24\%-ának volt az eGFR-értéke $<50 \mathrm{ml} / \mathrm{min} / 1,73 \mathrm{~m}^{2}$. Bebizonyosodott, hogy ez volt a dabigatran plazmakoncentrációja emelkedésének a legfontosabb tényezője, különösen akkor, ha az adag $2 \times 110 \mathrm{mg} / \mathrm{nap}$ volt. Az ajánlások szerint $30-50 \mathrm{ml} / \mathrm{min} / 1,73 \mathrm{~m}^{2}$ eGFR között napi $150 \mathrm{mg}$ napi kétszer javasolt, vagy $110 \mathrm{mg}$ napi kétszer megfontolandó, ha magas a vérzéses szövődmények rizikója; azaz, ha az életkor 75-80 év közötti, vagy gastritis, oesophagitis vagy gastro-oesophagealis reflux áll fenn, vagy más okból megnövekedett a vérzéskockázat egyéni mérlegelés alapján. A vérzés éves gyakorisága a vesefunkció függvényében a dabigatrannal kezelteknél a következő módon alakult: eGFR ml/min/1,73 m² $>80: 1,78 \%, 50-80: 3,05 \%,<50: 6,06 \%$. A warfarinnal kezeltek között ez a következőképpen alakult: eGFR ml/min/1,73 $\mathrm{m}^{2}>80: 3,01 \%, 50-80: 3,38 \%,<50: 5,06 \%$. $^{15}$

A dabigatran részlegesen dializálható, 2 óra után $62 \%, 4$ óra után $68 \%$ távolítható el, ezzel együtt dializált betegnek nem javasolt alkalmazása. ${ }^{16}$

\section{Rivaroxaban}

A rivaroxaban volt az első direkt Xa faktor gátló szer, amelyet az FDA elfogadott stroke-prevencióra PF-ban. Kiválasztása 35\%-ban a vesén át történik változatlan formában, míg 65\%-ban a citokróm P450 enzimrendszer bontja a májban; ezt követően ennek fele a vesén, másik fele a széklettel távozik.

A vesefunkció beszűkülése esetén koncentrációja megemelkedik, az ezt jellemző AUC 44\%-kal magasabb az eGFR 50-80 $\mathrm{ml} / \mathrm{min} / 1,72 \mathrm{~m}^{2}$ tartományban, 30-49 ml/min/1,72 m² között ez $52 \%$-ra emelkedik, míg ez alatt $64 \%$ az érték. ${ }^{17}$ A ROCKETAF vizsgálatba (Rivaroxaban Once Daily Oral Direct Factor Xa Inhibitor Compared with Vitamin K Antagonism for Prevention of Stroke and Embolism Trial) 14264 beteget vontak be, hogy összehasonlítsák 20 mg rivaroxaban hatását nem valvuláris PF-ban - amelyhez még két további rizikófaktor is társult - warfarinnal. Összeségében a rivaroxaban non-inferioritása igazolódott a stroke-prevenció és a szisztémás embolizáció vonatkozásában úgy, hogy a vérzéses szövődmények nem váltak gyakoribbá. A vizsgálati populáció 26\%-ának eGFR-értéke $30-49 \mathrm{ml} / \mathrm{min} / 1,72 \mathrm{~m}^{2}$ volt, ők $15 \mathrm{mg}$ rivaroxabant kaptak, ami 25\%-os dózisredukciót jelentett. Ebben a kohorszban a stroke és a szisztémás embolizáció prevenciója kevéssé volt hatékony a normális vesefunkciójúakhoz képest, de még így is hatékonyabb volt - 2,95/100 betegév -, mint a warfarin csoportjában - 3,44/100 betegév. A vérzéses szövődmények gyakorisága viszont mindkét kezelési csoportban magasabb volt. ${ }^{18}$

A rivaroxaban alkalmazására $30 \mathrm{ml} / \mathrm{min} / 1,72 \mathrm{~m}^{2}$ alatti vesefunkció esetén nincs tapasztalat; ESRD illetve hemodialízis esetén használata nem ajánlott. Az EINSTEIN-DVT és az EINSTEIN-PE vizsgálatokban a rivaroxaban hatását vizsgálták warfarinnal összevetve mélyvénás thrombosisban, illetve tüdőembóliában. Beszűkült vesefunkció (30-49 $\mathrm{ml} / \mathrm{min} / 1,72 \mathrm{~m}^{2}$ ) jellemezte a vizsgálati populáció 8 , illetve 10\%-át. Sem a rekurráló thrombembolisatio, sem az ehhez kapcsolódó halálozás, sem a vérzési kockázat vonatkozásában nem volt különbség a warfarinhoz képest egyik vizsgálatban sem..$^{19,20}$

\section{Apixaban}

Az apixaban is a direkt Xa faktor gátló szerek közé tartozik, amelynek renális clearence értéke a legalacsonyabb valamennyi DOAC közül, 25-27\%.21

Hatékonyságát és biztonságosságát warfarinnal összevetve az ARISTOTLE (Apixaban for Reduction in Stroke and Other Thromboembolic Events in Atrial Fibrillation) vizsgálat bizonyította, amelyben 18201 nem-valvuláris PF-ben szenvedő (+1 további CV rizikótényező) beteg adatait elemezték. A vizsgálatban részt vevők warfarint, vagy naponta $2 \times 5 \mathrm{mg}$ apixabant kaptak. Az adagot $2 \times 2,5$ mg-ra csökkentették, ha az alábbiak közül valamelyik állapot fennállt: szérum kreatininszint 1,5-2 mg/dl, életkor $\geq 80$ év, testsúly $\leq 60 \mathrm{~kg}$; ez a vizsgálati populáció 4,7\%-át érintette. Az apixaban mind az összetett végpont $(0,79$ HR [CI $0,66-0,95])$, mind a biztonságosság (HR 0,69 [CI 0,60-0,80]), mind a teljes halálozás tekintetében (HR 0,89 [CI 0,60-0,80]) szuperioritást mutatott warfarinnal összehasonlítva. ${ }^{22}$ Azon betegeket, akiknek szérum kreatininértéke meghaladta a $2,5 \mathrm{mg} / \mathrm{dl}$ szintet, vagy hemodialízisben részesültek, kizárták a vizsgálatból. Külön fókuszáltak a veseelégtelen betegekre is; a vesefunkciót 
három különböző módon számolt GFR-rel jellemezték: Cockroft-Gault-formula, KVB-EPI képlet, cisztatin C mérés, ${ }^{23,24}$ és szemben más vizsgálatokkal itt a bevonási határ $5 \mathrm{ml} / \mathrm{min} / 1,73$ $\mathrm{m}^{2}$-rel alacsonyabb, azaz $25 \mathrm{ml} / \mathrm{min} / 1,73 \mathrm{~m}^{2}$ volt. A CockroftGault-formula szerint számolt $25-50 \mathrm{ml} / \mathrm{min} / 1,73 \mathrm{~m}^{2}$ csoportba 3017 beteg, az $50-80 \mathrm{ml} / \mathrm{min} / 1,73 \mathrm{~m}^{2}$ csoportba 7587 beteg került. KVB-EPI szerint számolva a betegek száma 2843-mal, cisztatin C mérés alapján 2067-tel bővült. Mindez azonban a kedvező eredményeket nem befolyásolta. Az FDA 2014 januárjában dializált betegek számára is engedélyezte az apixaban-dózis csökkentett alkalmazását. ${ }^{25}$

$\mathrm{Az}$ AMPLIFY vizsgálatban az apixaban hatásosságát akut vénás thrombemboliában (VTE) vizsgálták enoxoparinnal/warfarinnal szemben. A vizsgálati populáció 7\%-ának volt az eGFR-értéke $<50 \mathrm{ml} / \mathrm{min} / 1,73 \mathrm{~m}^{2}$. Ebben a csoportban magasabb volt a VTE, az ehhez kapcsolódó halálozás és major vérzések gyakorisága. A beszűkült vesefunkció az apixaban hatékonyságát nem befolyásolta, de biztonságossági előny itt nem volt észlelhető.

\section{Edoxaban}

Az edoxaban a „legfiatalabb” a nálunk is kapható direkt Xa faktor gátló szerek között, amelynek renális clearence értéke $50 \%{ }^{26}$

A HOKUSAI-VTE vizsgálatban hasonlították össze az edoxaban hatékonyságát warfarinnal szisztémás VTE-s betegekben. 60 mg-os dózist alkalmaztak, de 30-50 ml/min/1,73 m² eGFRtartományban az adag csak $30 \mathrm{mg}$ volt. A VTE-recidívát, illetve a VTE-hez köthető haláleseteket tekintve edoxabankezelés mellett 3\%-os eseményrátát találtak az 5,9\%-os warfarinértékkel szemben. Mérsékelt vesefunkció-beszűkülés mellett nem volt különbség a vérzéses szövődmények gyakoriságában. ${ }^{27}$

Koretsune és munkatársai 3 hónapos, III. fázisú vizsgálatban napi egyszer $15 \mathrm{mg}$ edoxabant adtak beszűkült vesefunkciójú (eGFR 15-30 ml/min/1,73 m²) PF-betegeknek. Az találták, hogy az edoxaban plazmakoncentrációja, a vérzések kockázata hasonló volt, mint $30 \mathrm{mg}$ vagy $60 \mathrm{mg}$ dózis esetében normális vagy mérsékelten beszűkült vesefunkció (eGFR >50 $\mathrm{ml} / \mathrm{min} / 1,73 \mathrm{~m}^{2}$ ) esetén. ${ }^{28}$

I. fázisú, keresztezett vizsgálatban dializált vesebetegekben mérték a napi egyszer adott $15 \mathrm{mg}$ edoxaban plazmaszintjét és megállapították, hogy a dialízist követően nincs szükség további dózispótlásra, mert az edoxaban nem dializálható. ${ }^{29}$ Az FDA 2015 januárjában fogadta el a napi egyszer adott $60 \mathrm{mg}$ edoxabant nem valvuláris PF-ben szenvedő betegek számára stroke és szisztémás embolizáció prevenciójára. Az aktuális hazai gyógyszerelőirat a Cockroft-Gault-formula szerinti 15-50 ml eGFR esetén $30 \mathrm{mg}$ edoxaban napi egyszeri adását javasolja.

\section{A DOAC szerek összehasonlítása}

Elöljárójában le kell szögeznünk, hogy a DOACok vonatkozásában közvetlen összehasonlító klinikai vizsgálatok nem állnak rendelkezésre. Hogy az adott klinikai helyzetben melyik szer alkalmazása javasolt, az inkább a felhasználók korábbi klinikai tapasztalatain, vagy a szereket gyakrabban használók közléseiben foglaltakon múlik, ideértve a warfarinnal történő összehasonlításban végzett

\section{2. táblázat. A DOAC szerek farmakokinetika/farmakodinámiai összehasonlítása}

\begin{tabular}{|c|c|c|c|c|}
\hline & Dabigatran & Rivaroxaban & Apixaban & Edoxaban \\
\hline Paraméter & Ila (trombin) & Xa & Xa & Xa \\
\hline C max elérése (óra) & 2 & $2-4$ & $1-3$ & $1-2$ \\
\hline CYP-metabolizmus & nincs & $32 \%$ & $15 \%$ & $62 \%$ \\
\hline Biológiai hozzáférés & $7 \%$ & $80 \%$ & $66 \%$ & P-gp \\
\hline Transzporter & P-gp & P-gp/BCRP & $87 \%$ & $55 \%$ \\
\hline Fehérjekötődés & $35 \%$ & $>90 \%$ & $8-15$ óra & $10-14$ óra \\
\hline Féléletidő & $12-14$ óra & $9-13$ óra & $27 \%$ & $50 \%$ \\
\hline Vesekiválasztás & $80 \%$ & $65 \%$ & nincs hatás & nincs hatás \\
\hline Gastrointestinalis tolerancia & dyspepsia & nincs hatás & nincs hatás & $6-22 \%$ \\
\hline Étkezés hatása & nincs hatás & legalább +39\% & nem szükséges & lehetséges \\
\hline Bevétel étellel & nem szükséges & kötelező & naponta $2 \times$ & naponta $1 \times$ \\
\hline Adagolás & naponta $2 \times$ & naponta $1 \times$ & &
\end{tabular}




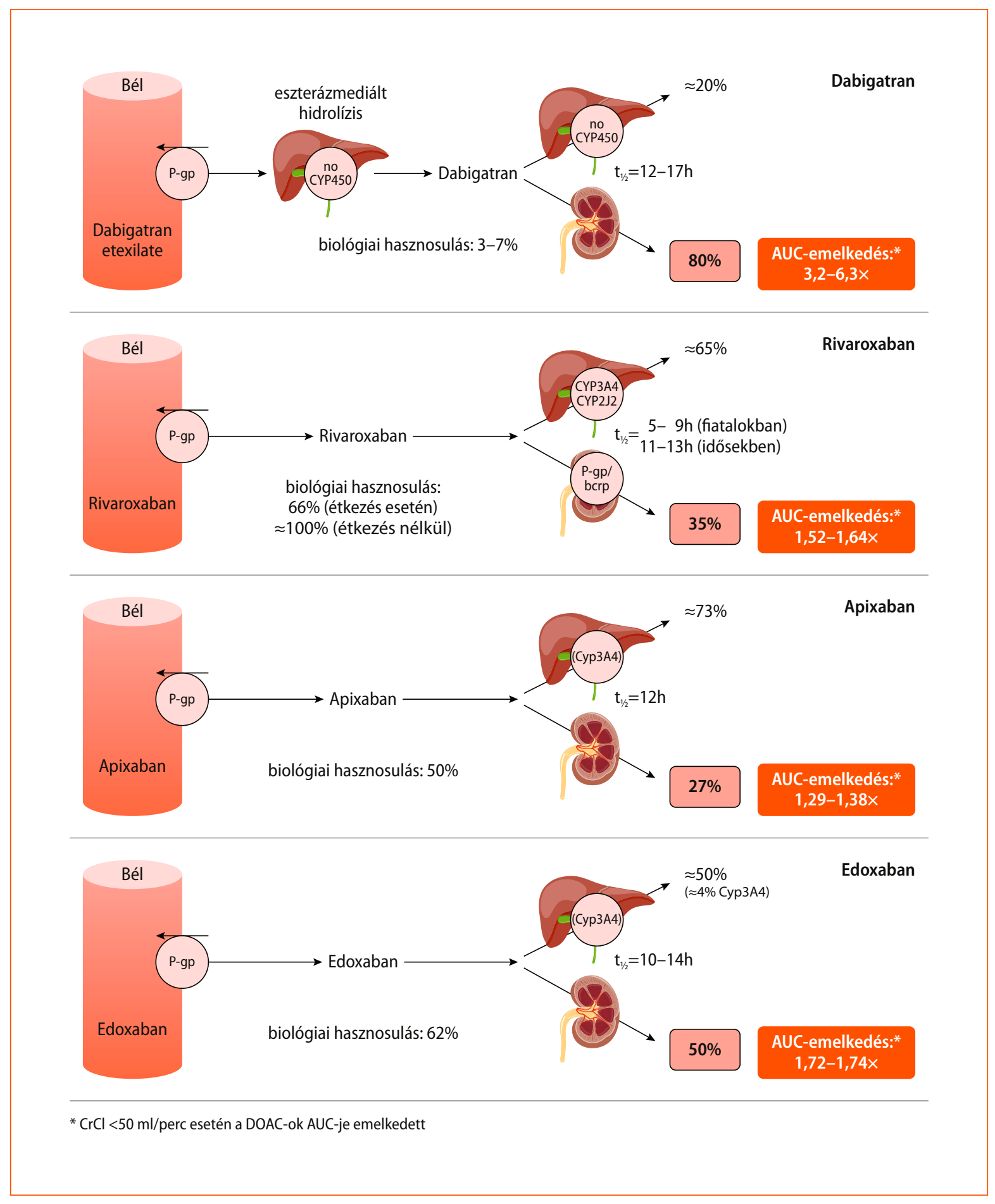

\section{1. ábra. A DOAC-ok eliminációja}

AUC: görbe alatti terület (area under curve); CrCl: kreatinin clearance; DOAC: új orális antikoaguláns (non-vitamin K oral anticoagulant); P-gp: P-glikoprotein; $t_{1 / 2}$ : felezési idő 
kisebb-nagyobb klinikai vizsgálatokat is. Némi segítséget jelenthetnek azok az összefoglaló ábrák és táblázatok, amelyek a szerek egyes tulajdonságait együtt mutatják be. A 2. táblázat a DOAC szerek farmakokinetikai és farmakodinámiás jellemzőit foglalja össze..$^{29,30,31,32,33,34}$

A vesén keresztül történő kiválasztás az apixaban esetében a legalacsonyabb, 27\%, így itt kell

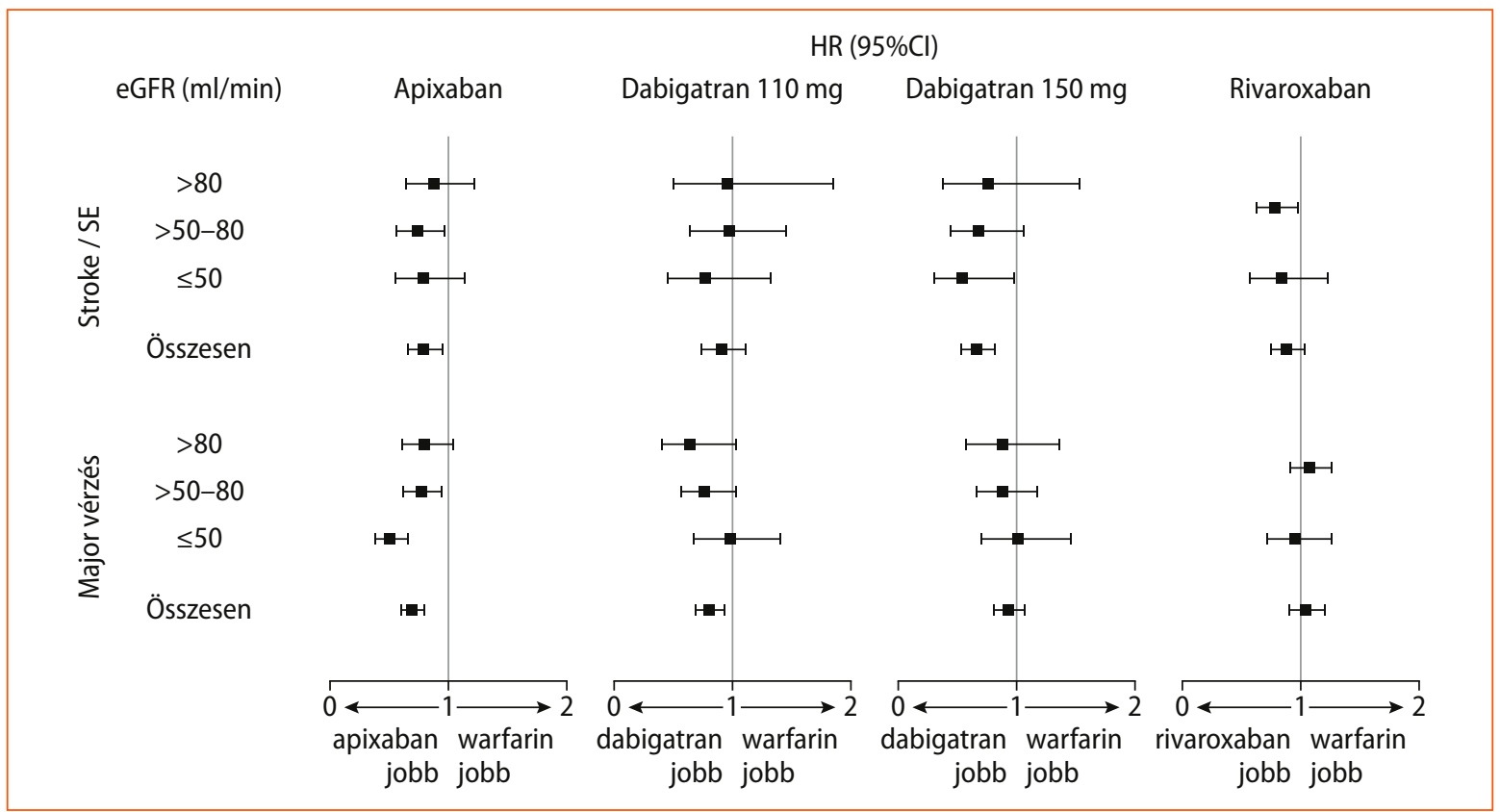

2. ábra. A DOAC-ok hatásossága és biztonságossága warfarinhoz képest vesefunkció alapán Nincsenek direkt összehasonlító vizsgálatok. A DOAC-ok relatív hatásosságára és biztonságosságára vonatkozó következtetéseket nem lehet levonni ezekböl az adatokból.

\section{3. táblázat. A DOAC szerek adagolási rendje a vesefunkció függvényében pitvarfibrilláló betegeknél}

\begin{tabular}{|c|c|c|c|c|}
\hline $\begin{array}{l}\text { Kreatinin } \\
\text { clearance }\end{array}$ & Apixaban & Dabigatran & Edoxaban & Rivaroxaban \\
\hline$>50 \mathrm{ml} /$ perc & $\begin{array}{l}\text { - napi } 1 \times 5 \mathrm{mg} \text { vagy } \\
\text { - napi } 2 \times 2,5 \mathrm{mg} \text {, ha kettő } \\
\text { teljesül az alábbiakból: } \\
\text { - kor } \geq 80 \text { év } \\
\text { - testtömeg } \leq 60 \mathrm{~kg} \\
\text { - kreatinin } \geq 1,5 \mathrm{mg} / \mathrm{dl}\end{array}$ & - napi $2 \times 150 \mathrm{mg}$ & $\begin{array}{l}\text { - napi } 1 \times 60 \text { mg vagy } \\
\text { - napi } 1 \times 30 \text { mg, ha } \\
\text { - Testtömeg } \leq 60 \mathrm{~kg} \\
\text { - Egyidejü P-gp-inhibitor } \\
\text { (ciclosporin, dronedaron, } \\
\text { erythromycin vagy } \\
\text { ketoconazol) szedése }\end{array}$ & - napi $1 \times 20 \mathrm{mg}$ \\
\hline $30-50 \mathrm{ml} /$ perc & $\begin{array}{l}\text { - napi } 1 \times 5 \mathrm{mg} \text { vagy } \\
\text { - napi } 2 \times 2,5 \mathrm{mg} \text {, ha kettő } \\
\text { teljesül az alábbiakból: } \\
\text { - kor } \geq 80 \text { év } \\
\text { - testtömeg } \leq 60 \mathrm{~kg} \\
\text { - kreatinin } \geq 1,5 \mathrm{mg} / \mathrm{dl}\end{array}$ & $\begin{array}{l}\text { - napi } 2 \times 150 \text { mg vagy } \\
\text { - megfontolandó a napi } \\
2 \times 110 \text { mg, ha magas a } \\
\text { vérzéses szövődmények } \\
\text { rizikója* }\end{array}$ & napi $1 \times 30 \mathrm{mg}$ & $\begin{array}{l}\text { - óvatos alkalmazás, } \\
\text { dóziscsökkentés napi } 1 \times 15 \\
\text { mg-ra }\end{array}$ \\
\hline $15-29 \mathrm{ml} /$ perc & napi $2 \times 2,5 \mathrm{mg}$ & ellenjavallt & napi $1 \times 30 \mathrm{mg}$ & napi $1 \times 15 \mathrm{mg}$ \\
\hline$<15 \mathrm{ml} /$ perc & ellenjavallt & ellenjavallt & ellenjavallt & ellenjavallt \\
\hline
\end{tabular}

* 75-80 év között, vagy közepesen súlyos vesekárosodás, gastritis, oesophagitis vagy gastro-oesophageális reflux vagy más okból megnövekedett vérzéskockázat 
a legkevésbé számítani kumulációra a vesefunkció beszűkülése esetén. Megjegyzendő, hogy a rivaroxaban bevételét kötelező étkezésre időzíteni. A DOAC-ok eliminációjának részletesebb kifejtése az 1. ábrán látható. ${ }^{28,29,30,31,32}$

A 2. ábrában összefoglalva láthatjuk warfarinnal összevetve a DOAC-ok hatékonyságát a stroke / szisztémás embolizáció / vérzéses szövődmények vo-

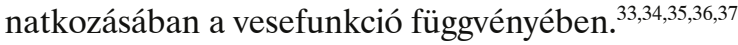

A 3. táblázat az egyes DOAC szerek adagolási előírását foglalja össze a vesefunkció függvényében PF-betegekben. ${ }^{28,29,30,31,32}$

\section{Gyakorlati megfontolások}

A DOAC terápián lévő, beszűkült vesefunkciójú betegek tervezett gondozást igényelnek, amely során az egyéni sajátosságok mellett az alábbi szempontokat kell figyelembe venni az EHRA 2018-as ajánlása alapján: ${ }^{13}$

- Adherencia ellenőrzése - minden vizit alkalmával; érdemes elhozatni a beteggel a gyógyszer dobozát, hogy együtt lehessen értékelni az esetleges eltéréseket. Segíthetnek az „okos”telefonos emlékeztető alkalmazások is.

- Minden vizit alkalmával keresni kell az esetleges embolizációra és/vagy vérzésre utaló még oly kicsiny jeleket is.

- Keresni kell, hogy esetlegesen nem jelenik-e meg valamilyen korábban nem volt mellékhatás.

- Érdeklődni kell, hogy nem kapott-e a beteg más szakmától valamilyen új gyógyszert, illetve nem kezdett-e szedni saját elhatározásból valamilyen étrendkiegészítőt vagy más „gyógyhatású” vagy „méregtelenítő” szert.

- Laboratóriumi vizsgálatok vonatkozásában a DOAC-ok plazmaszintjét nem kell ellenőrizni; az ún. alvadási paraméterek vizsgálata pedig kifejezetten félrevezető lehet, ezért azokat nem szabad vizsgálni. Évente ellenőrizni kell a hemoglobinszintet, a vese- és májfunkciót, ha csak az alapbetegség egyébként más ritmust nem kíván. Az ellenőrzéseket 6 havonta kell végezni, ha a beteg életkora 75 év feletti, különösen dabigatran szedése esetén, illetve ha a beteg általános állapota gyengébb. Minden olyan esetben, amely érintheti a vese- vagy májfunkciót, soron kívüli ellenőrzés szükséges.
- Beszűkült vesefunkció esetén, azaz ha az eGFR $<60 \mathrm{ml} / \mathrm{min} / 1,73 \mathrm{~m}^{2}$, az ellenőrzés gyakoriságát egy egyszerű képlettel határozhatjuk meg: eGFR/10, azaz ha pl. az eGFR 45 $\mathrm{ml} / \mathrm{min} / 1,73 \mathrm{~m}^{2}$, akkor $45 / 10=4,5$, vagyis 4,5 havonta javasolt az ellenőrzés.

\section{Következtetések}

A krónikus vesebetegeket a vesefunkció beszűkülésével arányosan fokozott $\mathrm{CV}$ morbiditás és mortalitás veszélyezteti. A fő kockázatot a thromboemboliás szövődmények jelentik, főként, ha PF is társul az alapbetegségekhez. Ez TAG és/vagy antikoaguláns kezelést tesz szükségessé. Ugyanakkor a vesefunkció romlásával arányosan nő a véralvadási zavarok és a vérzés kockázata is. Heparin ugyan biztosággal használható, de tartós alkalmazása a gyakorlatban nem kivitelezhető, míg az alacsony molekulasúlyú heparinok kumulálódnak az eGFR csökkenésekor. Jelenleg a leggyakrabban a VKA készítményeket alkalmazzák, azonban a rendszeres kontroll igénye a compliance-t szignifikánsan csökkenti, ugyanakkor fennáll a kumuláció veszélye is.

A DOAC-ok megjelenése az utóbbi évtized legnagyobb áttörését jelenti a véralvadásgátló kezelésben. Egyenrangúságukat megalapozott vizsgálatok bizonyították, és számos esetben sokkal jobb biztonságossági profilt mutattak, mint a VKA-k. Ugyanakkor a vesefunkció szűkülésével arányosan ezek az előnyök csökkennek, és dóziscsökkentés szükséges a vérzéses szövődmények kockázatának lehetséges minimalizálásához. A DOAC szerek renalis clearance-e különbözik, ezt tükrözik az adagolási elöírások is. Jelenleg az apixaban és az edoxaban alkalmazható $15 \mathrm{ml} / \mathrm{min} / 1,73 \mathrm{~m}^{2}$ eGFR-értékig.

Összehasonlító vizsgálatok nem állnak rendelkezésre és ilyenek tervezése, kivitelezése nem is várható. Ennek megfelelően továbbra is a személyre szabott, körültekintő mérlegelés lehet a beszűkült vesefunkciójú beteg számára legmegfelelőbb DOAC-választás alapja, amelyet követően ütemezett ellenőrzések szükségesek. Mert egy biztos: a thromboemboliás szövődmények ellen, különösen PF esetén, kötelező az antikoaguláns kezelés. A jelenleg még nyitott kérdésekre további vizsgálatok adhatnak választ, és különösen igaz ez a súlyos fokú KVB és ESRD esetében. 


\section{lrodalom}

1. Keith DS, Nichols GA, Guillion CM, Brown JB, Smith DH: Longitudinal followup and outcomes among a population with chronic kidney disease in a large managed care organization. Arch Intern Med 2004; 164: 659-663. doi:10.1001/archinte.164.6.659

2. Foley RN, Parfrey PS, Sarnak MJ: Clinical epidemiology of cardiovascular disease in chronic renal disease. Am I Kidney Dis 1998; $32(5$ Suppl 3): S112-S119. doi:10.1053/ajkd.1998.v32.pm9820470

3. Olesen JB, Lip GY, Kamper AL, Hommel K, Køber L, Lane DA: Stroke and bleeding in atrial fibrillation with chronic kidney disease. N Engl J Med 2012; 367: 625-635. doi:10.1056/NEJMoa1105594

4. Bauer A, Limperger V, Nowak-Gottl U: End-stage renal disease and thrombophilia. Haemostaseologie 2016; 36(2): 103-107. doi:10.5482/HAMO-14-11-0063

5. Lutz, J, Menke J, Sollinger D, Schinzel $H$, Thurmel K: Haemostasis in chronic kidney disease. Nephrol Dial Transplant 2014; 29(1): 29-40. doi:10.1093/ndt/gft209

6. Wattanakit K, Cushman M: Chronic kidney disease and venous thromboembolism: epidemiology and mechanisms. Curr Opin Pulm Med 2009; 15(5): 408-412. doi:10.1097/MCP.0b013e32832ee371

7. Jun M, James MT, Ma Z, Zhang J, Tonelli M, McAlister FA, et al: Warfarin initiation, atrial fibrillation, and kidney function: comparative effectiveness and safety of warfarin in older adults with newly diagnosed arial fibrillation. Am J Kidney Dis 2017; 69(6): 734-743. doi:10.1053/j.ajkd.2016.10.018

8. Han KH, O'Neill WC: Increased peripheral arterial calcification in patients receiving warfarin. J Am Heart Assoc 2016; 5(1): e002665. doi:10.1161/JAHA. 115.002665

9. Chan KE, Lazarus JM, Thadhani R, Hakim RM: Warfarin use associates with increased risk for stroke in hemodialysis patients with atrial fibrillation. $\mathrm{JAm}$ Soc Neprol 2009; 20(10): 2223-2233. doi:10.1681/ASN.2009030319

10. Brodsky SV: Warfarin-related nephropathy occurs in patients with and without chronic kidney disease and is associated with an increased mortality rate. Kidney Int 2011; 80(2): 181-189. doi:10.1038/ki.2011.44

11. Caluwé R, Pyfferoen L, De Boeck KD, De Vriese AS: The effects of vitamin $\mathrm{K}$ supplementation and vitamin $\mathrm{K}$ antagonists on progression of vascular calcification: ongoing randomized controlled trials. Clin Kidney J 2016; 9(2): 273-279. doi:10.1093/ckj/sfv146

12. Zou R, Tao J, Shi W, Yang M, Li H, Lin X, et al: Meta-analysis of safety and efficacy for direct oral anticoagulation treatment of non-valvular atrial fibrillation in relation to renal function. Thromb Res 2017; 160: 41-50. doi:10.1016/j.thromres.2017.10.013

13. Steffel J, Verhamme P, Potpara TS, Albaladejo P, Antz M, Desteghe L, et al.: Practical guide on the use of non-vitamin $K$ antagonist oral anticoagulants in patients with atrial fibrillation. Eur Heart J 2018; 39: 1330-1393. doi:10.1093/eurheartj/ehy136

14. van Ryn J, Stangier J, Haertter S, Liesenfeld KH, Wienen W, Feuring M, et al.: Dabigatran etexilate - a novel, reversible, oral direct thrombin inhibitor: interpretation of coagulation assays and reversal of anticoagulant activity. Thromb Haemost 2010; 103(6): 1116-1127. doi:10.1160/TH09-11-0758

15. Hijazi Z, Hohnloser SH, Oldgren J, Andersson U, Connolly SJ, Eikelboom JW, et al: Efficacy and safety of dabigatran compared with warfarin in relation to baseline renal function in patients with atrial fibrillation: a RE-LY (Randomized Evaluation of Long-term Anticoagulation Therapy) trial analysis. Circulation 2014; 129(9): 961-970. doi:10.1161/CIRCULATIONAHA. 113.003628

16. Stangier J, Rathgen K, Stahle H, Mazur D: Influence of renal impairment on the pharmacokinetics and pharmacodynamics of oral dabigatran etexilate: an open-label, parallel-group, single-centre study. Clin Pharmacokinet 2010; 49(4): 259-268. doi:10.2165/11318170-000000000-00000
17. Kubitza D, Becka M, Mueck W, Halabi A, Maatouk H, Klause N, et al.: Effects of renal impairment on the pharmacokinetics, pharmacodynamics and safety of rivaroxaban, an oral, direct Factor Xa inhibitor. Br I Clin Pharmacol 2010; 70(5): 703-712. doi:10.1111/j.1365-2125.2010.03753.x

18. Fox KA, Piccini JP, Wojdyla D: Prevention of stroke and systemic embolism with rivaroxaban compared with warfarin in patients with non-valvular atrial fibrillation and moderate renal impairment. Eur Heart J 2011; 32(19): 2387-2394. doi:10.1093/eurheartj/ehr342

19. Schulman S, Kearon C, Kakkar AK: Extended use of dabigatran, warfarin, or placebo in venous thromboembolism. N Engl J Med 2013; 368(8): 709-718. doi:10.1056/NEJMoa1113697

20. EINSTEIN Investigators; Bauersachs R, Berkowitz SD: Oral rivaroxaban for symptomatic venous thromboembolism. N Engl J Med 2010; 363(26): 2499-2510. doi:10.1056/NEJMoa1007903

21. Granger CB, Alexander JH, McMurray JJV, Lopes RD, Hylek EM, Hanna M, et al.: Apixaban vs. warfarin in patients with arial fibrillation. NEJM 2011; 365 : 981-992. doi:10.1056/NEJMoa1107039

22. Hu PT, Lopes RD, Stevens SR, Lars W, Laine T, Alexander JH, et al.: Efficacy and safety of apixaban compared with warfarin in patients with atrial fibrillation and peripheral artery dsease: insights from the ARISTOTLE trial. J Am Heart Asso 2017; 6(1): e004699. doi:10.1161/JAHA.116.004699

23. Dias C, Moore KT, Murphy J, Ariyawansa J, Smith W, Mills RM, et al.: Pharmacokinetics, pharmacodynamics, and safety of single-dose rivaroxaban in chronic hemodialysis. Am J Nephrol 2016; 43: 229-236. doi:10.1159/000445328

24. Squibb B-M, Gambone L: Eliquis (apixaban) 2.5 and $5 \mathrm{mg}$ Tablets. Available at: https://www.accessdata.fda.gov/drugsatfda_docs/appletter/2014/ 2021550rig1s002ltr.pdf

25. Giugliano RP, Ruff CT, Braunwald E, Murphy SA, Wiviott SD, Halperin JL, et al.: ENGAGE AF-TIMI 48 Investigators: Edoxaban vs. warfarin in patients with atrial fibrillation. N Engl J Med 2013; 369(22): 2093-2104. doi:10.1056/NEJMoa1310907

26. Hokusai-VTE Investigators; Buller HR, Decousus H: Edoxaban vs. warfarin for the treatment of symptomatic venous thromboembolism. N Engl I Med 2013; 369(15): 1406-1415. doi:10.1056/NEJMoa1306638

27. Koretsune Y, Yamashita T, Kimura T, Fukuzawa M, Abe K, Yasaka M: Shortterm safety and plasma concentrations of edoxaban in Japanese patients with non-valvular atrial fibrillation and severe renal impairment. Circ J 2015; 79(7): 1486-1495. doi:10.1253/circj.CJ-14-0942

28. Parasrampuria DA, Marbury T, Matsushima N: Pharmacokinetics, safety, and tolerability of edoxaban in end-stage renal disease subjects undergoing haemodialysis. Thromb Haemost 2015; 113(4): 719-727. doi:10.1160/TH14-06-0547

29. Heidbüchel $H$, Verhamme P, Alings M, Antz M: Updated European heart rhythm association practical guide on the use of non-vitamin Kantagonist anticoagulants in patients with nonvalvular atrial fibrillation. Europace 2015; 17: 1467-1507. doi:10.1093/europace/euv309.

30. Apixaban SmPC. Available at: www.ema.europa.eu (accessed March 2017)

31. Dabigatran SmPC Available at: wwww.ema.europa.eu (accessed March 2017)

32. Rivaroxaban SmPC Available at: www.ema.europe.eu (accessed March 2017)

33. Edoxaban SmPC Available at: www.ema.europe.eu

34. Capranzano P, Miccichè E, D'Urso L, Privitera F, Tamburino C: Personalizing oralanticoagulant treatment in patients with atrial fibrillation. Expert Rev Cardiovasc Ther 2013; 11: 959-973. doi:10.1586/14779072.2013.818819

35. Granger $C B$, Alexander $\mathrm{JH}$, McMurray JJV: Apixaban vs. warfarin in patients with atrial fibrillation. N Engl J Med 2011; 365: 981-992. doi:10.1056/NEJMoa1107039 
36. Connolly SJ, Ezekowitz MD, Yusuf S, Eikelboom J, Oldgren J, Parekh A, et al.: RE-LY Steering Committee and Investigators: Dabigatran vs. warfarin in patients with atrial fibrillation. N Engl J Med 2009; 361: 1139-1151. doi:10.1056/NEJMoa0905561

37. Patel MR, Mahaffey KW, Garg J, Pan G, Singer DE, Hacke W, et al:: ROCKET AF Investigators. Rivaroxaban vs. warfarin in nonvalvular atrial fibrillation. N Engl J Med 2011; 365: 883-891. doi:10.1056/NEJMoa1009638
Közlésre érkezett: 2018 . augusztus 22.

Közlésre elfogadva: 2018. november 14.

A szerzö levelezési címe:

\section{Prof. Dr. Ábrahám György}

Szegedi Tudományegyetem, ÁOK I. Belgyógyászati Klinika

6720 Szeged, Korányi fs. 10.

E-mail: abraham.gyorgy@med.u-szeged.hu 